\section{The impact of sports mega-events on health and environmental rights in the city of Rio de Janeiro, Brazil}

\author{
O impacto dos megaeventos esportivos sobre os \\ direitos à saúde e ao meio ambiente na \\ cidade do Rio de Janeiro, Brasil \\ El impacto de los mega-eventos deportivos sobre \\ los derechos a la salud y al medio ambiente en la \\ ciudad de Río de Janeiro, Brasil
}

Rodrigo Machado Vilani 1,2

Carlos José Saldanha Machado ${ }^{3}$
1 Universidade Federal do Estado do Rio de Janeiro, Rio de Janeiro, Brasil. 2 Universidade Cândido Mendes, Campos, Brasil. 3 Instituto de Comunicação e Informação Científica e Tecnológica em Saúde, Fundação Oswaldo Cruz, Rio de Janeiro, Brasil.

Correspondence R. M. Vilani

Universidade Federal do Estado do Rio de Janeiro. Av. Pasteur 458, Rio de Janeiro, RJ 22290-240, Brasil. r_vilani@yahoo.com.br

\begin{abstract}
The aim of this study is to discuss the contradictions of the Olympic Games legacy for health and environment in the city of Rio de Janeiro, Brazil. Public policies for sports mega-events have been criticized for contributing to and deepening the city's historical socio-spatial inequalities. Based on document research and data analysis, the article focused on establishing a proposal for a sustainable city, as provided in Law 10,257/2001, the so-called City's Statute. The article concludes with remarks on Olympic urban planning, its market orientation, and failures to overcome public health and environmental sanitation problems that will persist as a legacy after 2016.
\end{abstract}

City Planning; Sanitation; Urban Health

\section{Resumo}

O objetivo do presente trabalho é discutir as contradições do legado olímpico em relação à saúde e ao meio ambiente na cidade do Rio de Janeiro, Brasil. As políticas públicas, orientadas pelos megaeventos esportivos, são criticadas por contribuírem e aprofundarem as históricas desigualdades socioespaciais do município. Com base em pesquisa documental e análise de dados, adotou-se uma abordagem voltada para a construção de uma proposta de cidade sustentável conforme estabelece $a$ Lei no 10.257/2001 -o Estatuto da Cidade. Conclui-se tecendo considerações gerais e específicas sobre o urbanismo olímpico, sua orientação mercadológica e as falhas na superação de problemas de saúde pública e saneamento ambiental, que permanecerão como herança após 2016.

Planejamento de Cidades; Saneamento; Saúde Urbana 


\section{Introduction}

The major sports events (or mega-events) already held in the city of Rio de Janeiro, Brazil, namely the Pan American Games in 2007, the Confederations Cup in 2013, and the FIFA World Cup in 2014, plus the Olympic and Paralympic Games to be hosted in 2016 are presented to the population as a legacy for the city.

By hosting such large events, Brazil, together with South Africa, which hosted the FIFA World and Confederations Cup (2010 and 2009, respectively), and India, host of the Commonwealth Games in 2010, consolidate the underlying concept of mega-events as "an excellent opportunity for countries of the so-called Global South to leverage local development and be included on the list of 'modern countries"' 1 (p. 121).

This involves not only the countries of the "South", but also the entire bloc of the planet's emerging economic powers (Brazil, Russia, India, China, and South Africa - BRICS). China hosted the Olympic Games in 2008, and Russia hosted the Winter Olympic Games in 2014 and will host the FIFA World Cup in 20182.

The various expectations in relation to the legacy, allowed by sizeable public investments, are associated with infrastructure, various sports facilities, public security 1 , new jobs, public transportation, urban mobility, improved image, and greater competitiveness for the city's tourism industry 3 , among others, in addition to health promotion in the urban space 4 . The aim of this article is thus to identify and discuss the impacts of urban restructuring in the city of Rio de Janeiro associated with sports megaevents, focusing on the issues of infrastructure and health promotion.

However, it is impossible to overlook the adverse consequences of urban interventions currently under way. Magalhães 5 calls attention to the changes in uses of the urban space by various social segments and classes, made possible by significant changes in urban planning legislation. The author highlights the "Morar Carioca" lowcost housing program as one of these legacies, focused specifically on upgrading Rio's favelas by 2020. In the Morro da Providência slum community, the program "provides for the removal of 832 homes, some of which due to 'geotechnical, structural, and health risk' issues [...] in addition to the resettlements needed to conduct the urban upgrading program, including 'decreased community crowding" 6 (p. 10). This sparked criticism for the program, which "reedits a historical view of the favelas as maladjusted urban spaces within an otherwise organized and rationally planned city" 5 (p. 110).
This critical position corroborates Demarzo et al. ${ }^{4}$ (p. 8) on the importance of debating "the economic and urban impact assessment of the Olympic Games in relation to public health in Brazil." Seven years after the Pan American Games in 2007, more than two years after the Confederations Cup, and having recently cohosted the FIFA World Cup, the city now has a year to prepare for the 2016 Olympics. As we will present next, the discussions and contributions towards improving public health and sanitation in the Olympic City still involve social and structural inequalities in Rio's urban development model. Therefore, the discussion of the Olympic legacy for health and the environment contains "a particularly important challenge for a city whose internal structure is historically marked by socio-spatial exclusion and still displays an unfortunate array of chronic problems in housing, sanitation, transportation, and medical and hospital infrastructure, among others" 7 (p. 53).

Health and the environment are constitutionally guaranteed social rights, based on a broad and diffuse array of competencies involving the Federal government and States and $\mathrm{Mu}$ nicipalities. These rights are highly relevant for achieving the greater goal of Brazil's 1988 Federal Constitution, namely to ensure decent life for present and future generations. Since the basis for these rights is beyond debate, the study agrees with the assumptions by Bobbio ${ }^{8}$ (p. 15) that "human rights are desirable things, that is, ends that deserve pursuing", but which still lack full recognition. In light of this understanding, we contend that this discussion does not arise from a philosophical problem involving the basis for such rights, but from a political and legal issue related to the right to health and a decent environment.

These social rights are guaranteed by Brazil's 1988 Constitution, (Articles 5, 196, 200, and 225), but in the country's current urban scenario they have been "constantly challenged as to the extent of their enforceability, regardless of positive action by legislators or even the government administration, that is, whether it is possible to generate subjective rights for individuals, and if so, in which cases" 9 (p. 58). The disordered growth of Brazilian cities is a direct part of this context, as a process of human expansion often dissociated from the capacity for support from the surroundings. This mismatch leads to widespread problems, an urban tragedy for Brazil, marked by “floods, landslides, water pollution, air pollution, degraded soil surface permeability, deforestation, crowded housing, epidemics, violence, etc.” 10 (p. 22).

To discuss the urban space thus involves " understanding Brazilian cities as the main motor 
force for the economy and thus one of the main factors for competitiveness in the world context; understanding the quality of urban spaces as one of the principal indicators for human development will mean a major change in the current approach by public policies for the use of urban spaces. Brazil has now focused on reducing poverty and social inequality by increasing wages and improving the population's access to health, education, and low-income housing" 11 (p. 64).

The definition of the object of study in the city of Rio de Janeiro, with a current population of 6,320,446 (Instituto Brasileiro de Geografia e Estatística.Cidades@. http://bit.ly/louZwgx, accessed on 06/Nov/2012), includes the resumption of urban investments in mobility and transportation, public security, recovery and conservation of downtown Rio and the port area, among others, especially driven by the mega-events hosted by the city.

The city of Rio de Janeiro currently includes $1,860,405$ private households in urban areas with substandard sites and services, such as: 504,117 lacking tree cover in the vicinity, 90,505 with open-air sewage in the vicinity, and 80,119 on lots with accumulated garbage (Instituto Brasileiro de Geografia e Estatística. Cidades@. http://bit. ly/louZwgx, accessed on 06/Nov/2012). According to a study by the "Treat Brazil" Institute 12, Rio de Janeiro reported treating only $60 \%$ of its sewage in 2007 and only $48 \%$ in 2008 . It is necessary not to miss the window of opportunity created by the major sports events in order to lay the grounds for a shift from the shortsighted public planning paradigm to long-term, on-going, and sustainable management, based on a project for a lasting, socially inclusive, and environmentally responsible city.

To achieve the central objective of this article, we opted for a document search and data analysis based on the legal principles related to health and the environment within the current model for Olympic urban planning under way in Rio de Janeiro. The identification of the principal aspects related to the selected policies compared different areas of the city (according to planning areas and administrative regions) in order to show the similarities and differences between the actions planned and implemented for the Olympic City and the urban development model established under the country's legal order. The quantitative analysis drew on data from 2010 on the presence of open-air sewage and garbage accumulated around households, taken from a survey by the Brazilian Institute of Geography and Statistics (IBGE) 13 and data from the Rio de Janeiro Municipal Health Secretariat (SMS-RJ) on dengue fever cases from 2007 to 2013 and hepa- titis A and leptospirosis, both for 2007 to 2012 (SMS-RJ. Dengue: Dados Epidemiológicos. http:// www.rio.rj.gov.br, accessed on 12/Dec/2013). This methodology aimed to compare two current urban dimensions: infrastructure and sanitation characteristics and health conditions, in the case of dengue, in the attempt to grasp possible interrelations. These data were analyzed comparatively between the spaces in the city of Rio de Janeiro and by elaborating indicators based on proportions and rates.

This article is intended to contribute to an interface between technical and scientific studies and socio-environmental demands, by strengthening the debate on the need to "redirect the city's resources and wealth more fairly in order to fight the situations of [environmental] economic and social inequality" 14 (p. 81).

\section{Olympic urban planning in Rio de Janeiro}

Rio de Janeiro has undergone urban transformations in various areas of the city as part of the reordering process prior to hosting the various sports mega-events beginning in 2007.

In this context of spatial changes, the Olympic urban planning concept, defined as " $a$ set of assumptions and interventions in cities that host major Olympic events" (Muñoz, 1996, apud Mascarenhas 15; p. 27), has achieved great importance in the discussions on the legacy of this new city planning and management format.

Beginning with the Pan American Games, we can identify the consolidation of a new hub in Rio's urban planning, Barra da Tijuca, a socially privileged region that has concentrated most of the investments, characterizing an exclusionary and segregating model from the socio-spatial point of view $7,15,16$.

Therefore, theoretical efforts to analyze the intervention by mega-events in the city include the discussion of a new urban configuration and political, socioeconomic, and cultural dynamics that direct and are directed towards a new city, with new features and some segments of the population benefited, while others are excluded. Within this context, it is thus not possible to limit the analysis to a single dimension. We need to understand urban policy within the concept of public policy as " $a$ holistic field, that is, an area that situates various units in organized totalities" 17 (p. 26), and in the case at hand, how the urban planning policy for sports mega-events has impacted the health, sanitation, and environmental sectors. 
Sanitation, which includes running water supply, sewerage, garbage disposal and street cleaning, solid waste management, and drainage and management of urban rainwater, comprises an important link between public health and the environment, because "inadequate sanitation conditions can cause contamination of springs, waterways, and soil, silting of rivers, and floods, contributing to the formation of environments that are prone to the proliferation of diseasetransmitting agents" 18 (p. 792).

In an increasingly complex urban scenario, this emphasizes the close relationship between environmental, social, economic, political, and scientific issues and their implications for the quality of the environment and the population's health and the "perception of the importance that health and the environment converge in both concept and in practice" 19 (p. 74). Other socioeconomic factors such as income distribution and general conditions in sanitation, work, and housing also contribute directly to the health-disease process $20,21,22$.

According to estimates, by 2050 two-thirds of the world's population of 9 billion inhabitants will be living in cities 23 , further emphasizing the issue of the model for cities that we plan to build for future generations. This perspective was the basis for the recent multilateral discussions hosted in Rio de Janeiro, of which we highlight three of the thematic areas (Water and Sanitation; Sustainable Cities and Human Settlements; Health and Population) found in the document The Future We Want, the result of the United Nations Conference on Sustainable Development, Rio+20 24. The document mentions water as the central element for sustainable development, besides its importance for ecosystems and sanitation. "If cities are well planned and developed, including integrated planning and management methods, they can promote economically, socially, and environmentally sustainable societies" 24 (p. 28). Meanwhile, such actions should take the population's health as a whole into account, and especially that of poor and vulnerable groups.

As highlighted in the Introduction, megaevents have become a development opportunity for countries of the South and the BRICS members. Within the myriad of possible questions and approaches, as already mentioned, those related to economic impacts are among the most difficult to analyze. For example, Domingues et al. 25 point to the reduction in other expenses due to public investment in the events and even the increase in the public debt. Among the uncertainties, investments by countries hosting sports events and that have transition economies may contribute to economic growth, but also hamper development after the events are over 26 .

It is important to analyze the efficiency of government investments, in this case on sports mega-events, as compared to areas like health and education 25 .

While the city of Rio de Janeiro has benefited from investments that should lead to long-term returns for the population, like improvements in sanitation, such improvements have still failed to reach the majority of the population. According to data by Instituto Trata Brasil ("Treat Brazil” Institute) 27 , in 2011 Rio de Janeiro ranked 57th among the country's 100 largest cities in terms of sewage disposal, trailing behind other cities in the State of Rio de Janeiro such as Niterói, Petrópolis, and Campos dos Goytacazes (12th, $27^{\text {th }}$, and $50^{\text {th }}$, respectively).

How can we conceive the Olympic legacy in the market context that has created and shaped Rio de Janeiro's new urban infrastructure? In order to answer this question, we propose to analyze data on health and the environment in Rio over the course of the sports mega-events events held thus far, namely from 2007 to 2013.

\section{Health and environment and the Olympic Games cycle}

According to the Department of Epidemiological Surveillance of the Brazilian Ministry of Health, "So-called 'old' diseases such as cholera and dengue fever have reemerged, and important endemic diseases such as tuberculosis and meningitides still persist, making this group of diseases an ongoing public health problem, even for developed countries. This scenario reflects the social transformations that have occurred since the 1970s, with accelerated urbanization, migration, environmental changes, and ease in communication between continents, countries, and regions, contributing with other factors to the current epidemiological pattern of transmissible diseases worldwide" 28 (p. 38).

A recently emerging demand thus relates directly to more in-depth research into the points of contact between health and the environment. An analysis of this issue thus requires focusing attention on health and environmental sector policies as tools for building and consolidating a fair, healthy, and sustainable society. This concern has also oriented the trend towards practices in sanitation that extend beyond the traditional concept to incorporate environmental aspects (from both the physical and biotic environment) into the population's health concerns 29. 
This perspective is corroborated by the profile of infectious diseases in Brazil, according to an analysis by the Ministry of Health, exposing the "country's fragile urban environmental structures, leaving the population vulnerable to diseases that had apparently already been overcome" 28 (p. 45). Thus, how is it possible to overcome the gap between urban environmental planning and the necessary improvements in the population's health conditions?

By way of example, Rio de Janeiro's topography and historically disordered occupation "can expand the possibilities for (and intensity of) contact between the leptospirosis pathogen, reservoirs, and susceptible individuals". According to the current article's understanding, preventive measures should focus on basic sanitation, since "the incidence of leptospirosis in urban areas is heavily influenced by environmental conditions and urban infrastructure" 30 (p. 7).

Another example is the increase in dengue fever cases in the city. According to the "Rio Como Vamos" Organization (Indicadores. http://bit. ly/1iDBcHL, accessed on 12/Nov/2012), based on a survey by the Rio de Janeiro Municipal Health Secretariat, there was a $93.95 \%$ increase in dengue fever cases from the third quarter of 2011 to that of 2012, with 2,480 and 4,810 cases in the city, respectively. By way of comparison, a total of 116,351 dengue fever cases were reported in Brazilian metropolitan areas as a whole in 2012, according to data from the Information System for Diseases of Notification (SINAN. Dengue. http:// bit.ly/1hC6Na8, accessed on 12/Nov/2012). The Greater Rio de Janeiro Metropolitan Area had the highest incidence, with 47,481 cases $(40.8 \%$ of the total), more than double that of the second metropolitan area, Fortaleza, with 19,727 reported cases. To highlight the urban health problem, Machado \& Filipecki ${ }^{31}$ point to the fifth dengue fever epidemic in Rio de Janeiro among other "old and established diseases", along with emerging infectious diseases such as AIDS and swine and avian influenza, and non-communicable diseases. The authors correlate "the combination of factors such as environmental changes, demographic dynamics, cultural practices in hygiene, absence or inefficiency of the public sector, and expansion and increase in the circulation of persons and merchandise through increasingly rapid transportation systems" 36 (p. 89).

Two major dengue outbreaks occurred during the sports mega-events cycle, the first in $2008(120,917$ cases) and the most recent in 2012 (133,598 cases). In 2013 the total number of dengue cases $(66,278)$ was close to that in 2007 $(69,088)$, showing that no progress had resulted from policies implemented during that period (except for 2009 and 2010, with 2,727 and 3,268 cases, respectively) (SMS-RJ. Dengue: Dados Epidemiológicos. http://www.rio.rj.gov.br, accessed on $12 / \mathrm{Dec} / 2013$ ).

Table 1 shows the data for 2013, disaggregated by planning and administrative areas in the city of Rio de Janeiro (some neighborhoods were left out to adjust to the size of the article), according to the percentage of cases in the local population.

Table 1 highlights the Paquetá, Rocinha, and Guaratiba neighborhoods with the highest percentages of the population affected by dengue. Comparing the data to per capita income in the administrative areas (Figure 1) shows a correlation between low income and high dengue incidence.

Table 2 provides a schematic trend during the period for two other diseases related to sanitation problems, namely hepatitis A and leptospirosis.

Table 2 also shows the overall increase in hepatitis A in the city, most significantly in two planning areas (3.3 and 5.2). Planning areas 5.2 and 3.1 also show the most significant fluctuations in cases of leptospirosis. Campo Grande and Guaratiba, neighborhoods included in the above-mentioned planning area 5.2, belong to the two lowest mean income brackets (Figure 1).

Figures 2 and 3, prepared with data from the IBGE 13 on the areas around households, show that such conditions also correlated with per capita income.

The Port Region and the Complexo do Alemão and Rocinha favelas showed the highest rates of open-air sewage and accumulated garbage around households. Such conditions violate fair access to the city in the broadest sense, and to health in the sense of human rights in the urban area.

This calls for a reading of reality that integrates the economic, social, political, scientific, and environmental spheres, focused on a fair society with solidarity, orienting action aimed at ensuring, for the present and future generations, the right to access to an ecologically balanced environment, basic sanitation, healthy foods, and safe leisure and recreation, that is, the right to a decent life in Brazilian cities 32 .

Brazil needs to monitor changes in policies for investments in health after the conclusion of the sports mega-events cycle with the Olympic Games in 2016. Declarations by the Minister of Health raised expectations among the FIFA World Cup host cities, with a set of health interventions and investments, particularly in urgent and emergency care and epidemiological surveillance 33 .

Thus, in keeping with the model proposed by Soares et al. 29 , it is necessary to probe into Rio de Janeiro's urban planning for a medium and long- 
Table 1

Dengue cases by Planning Area and Administrative Region. Rio de Janeiro, Brazil.

\begin{tabular}{|c|c|c|c|}
\hline Planning Areas and Administrative Regions & Population * & $\begin{array}{c}\text { Dengue cases } \\
\text { (2013) }\end{array}$ & $\%$ \\
\hline Total & $6,320,446$ & 66,278 & 1.05 \\
\hline Planning Area 1 & 297,976 & 4,838 & 1.62 \\
\hline I. Portuária (Port) & 48,664 & 889 & 1.83 \\
\hline II. Centro (Downtown) & 41,142 & 603 & 1.47 \\
\hline III. Rio Comprido & 78,975 & 1,377 & 1.74 \\
\hline VII. São Cristóvão & 84,908 & 1,037 & 1.22 \\
\hline XXI. Paquetá & 3,361 & 158 & 4.70 \\
\hline XXIII. Santa Teresa & 40,926 & 774 & 1.89 \\
\hline Planning Area 2.1 & 638,050 & 8,572 & 1.34 \\
\hline IV. Botafogo & 239,729 & 2,850 & 1.19 \\
\hline V. Copacabana & 161,191 & 2,732 & 1.69 \\
\hline VI. Lagoa & 167,774 & 1,426 & 0.85 \\
\hline XXVII. Rocinha & 69,356 & 1,564 & 2.26 \\
\hline Planning Area 2.2 & 371,120 & 5,305 & 1.43 \\
\hline VIII. Tijuca & 181,810 & 2,732 & 1.50 \\
\hline IX. Vila Isabel & 189,310 & 2,573 & 1.36 \\
\hline Planning Area 3.1 & 886,551 & 9,367 & 1.06 \\
\hline X. Ramos & 153,177 & 1,759 & 1.15 \\
\hline XI. Penha & 321,887 & 3,353 & 1.04 \\
\hline XX. Ilha do Governador & 212,574 & 3,337 & 1.57 \\
\hline XXIX. Complexo do Alemão & 69,143 & 115 & 0.17 \\
\hline XXX. Maré & 129,770 & 803 & 0.62 \\
\hline Planning Area 3.2 & 569,970 & 4,332 & 0.76 \\
\hline XII. Inhaúma & 134,349 & 1,352 & 1.01 \\
\hline XIII. Méier & 397,782 & 2,913 & 0.73 \\
\hline XXVIII. Jacarezinho & 37,839 & 67 & 0.18 \\
\hline Planning Area 3.3 & 942,638 & 7,177 & 0.76 \\
\hline XIV. Irajá & 202,952 & 2,586 & 1.27 \\
\hline XV. Madureira & 372,555 & 2,598 & 0.70 \\
\hline XXII. Anchieta & 158,318 & 783 & 0.49 \\
\hline XXV. Pavuna & 208,813 & 1,210 & 0.58 \\
\hline Planning Area 4 & 909368 & 7937 & 0.87 \\
\hline XVI. Jacarepaguá & 572,030 & 5,127 & 0.90 \\
\hline XXXIV. Cidade de Deus & 36,515 & 132 & 0.36 \\
\hline XXIV. Barra da Tijuca & 300,823 & 2,678 & 0.89 \\
\hline Planning Area 5.1 & 671,041 & 7,687 & 1.15 \\
\hline XXXIII. Realengo & 243,006 & 2,722 & 1.12 \\
\hline XVII. Bangu & 428,035 & 4,965 & 1.16 \\
\hline Planning Area 5.2 & 665,198 & 6,835 & 1.03 \\
\hline XVIII. Campo Grande & 542,084 & 4,046 & 0.75 \\
\hline XXVI. Guaratiba & 123,114 & 2,789 & 2.27 \\
\hline Planning Area 5.3 & 368,534 & 3,173 & 0.86 \\
\hline XIX. Santa Cruz & 368,534 & 3,173 & 0.86 \\
\hline
\end{tabular}

* Population Census 201013.

Source: Rio de Janeiro Municipal Secretariat (http://www.rio.rj.gov.br, accessed on 12/Dec/2013). 


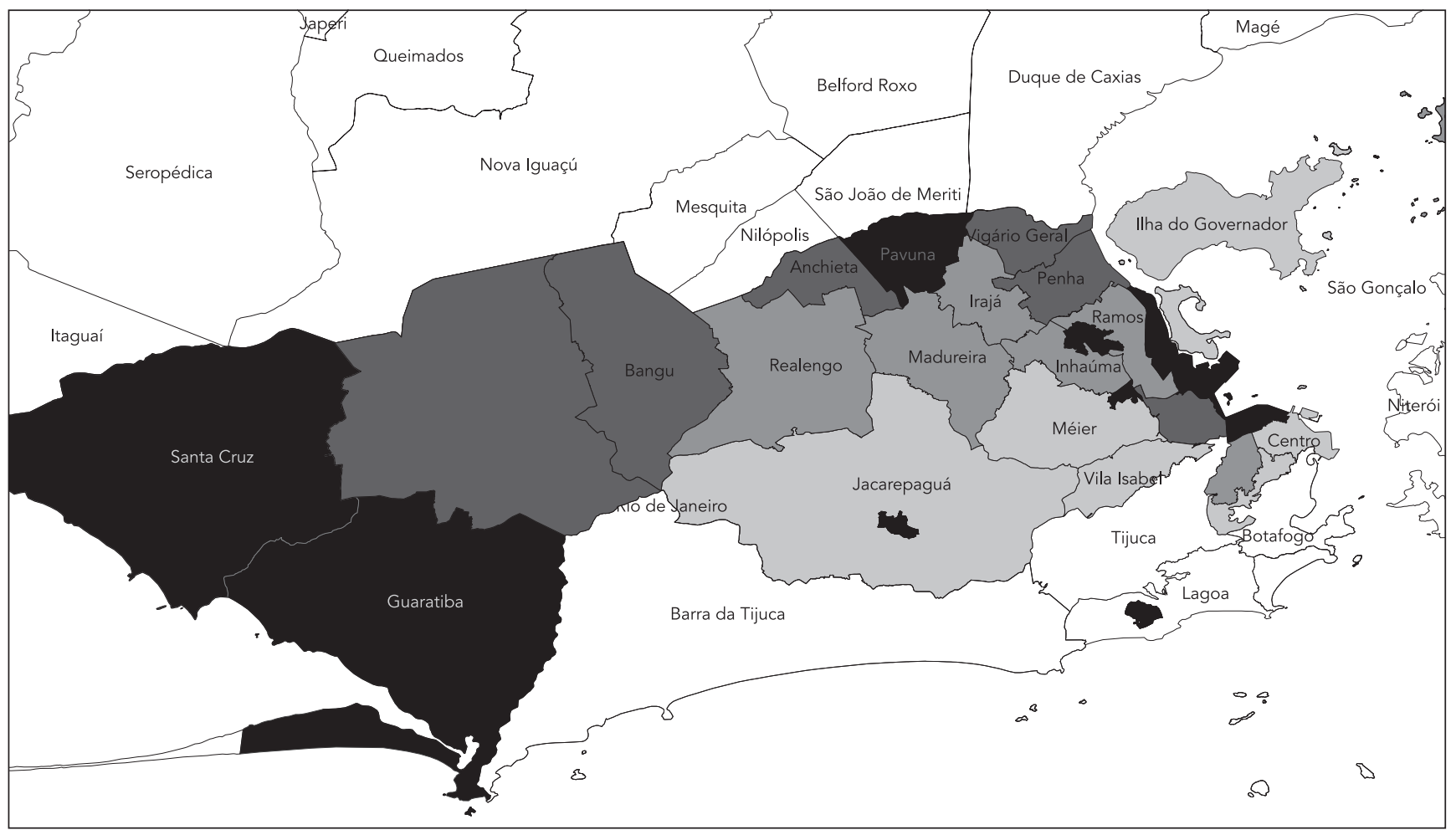

Per capita income (BRL)

$390.80-560.20$

$560.20-816.58$

$816.58-1,181.72$

$1,181.72-2,316.34$

$2,316.34-5,572.84$

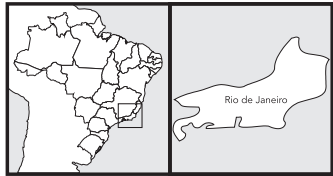

0

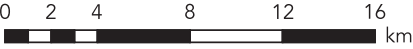

term analysis of the impacts of urban interventions on health and include the entire population in this process (which thus far has been segregating and exclusionary.

\section{Final remarks}

The article aimed to add theoretical elements to the debate on sports mega-events, a theme which still lacks academic and scientific stud- ies 3 , in order to at least partially contribute to achieving the legacies so widely publicized in the media. The principal legacy pertains exactly to counterproductive or unimplemented measures such as flagrant "abusive spending" and "inconsequential projects", highlighting the importance of discussing "the borders between public and private" 34 .

Analyses of the mega-events through the selected literature on sports economics, public health, and sanitation particularly reveal the diffi- 
Table 2

Hepatitis A and leptospirosis cases by Planning Area and Administrative Region. Rio de Janeiro, Brazil.

\begin{tabular}{|c|c|c|c|c|c|c|c|c|c|c|c|c|c|}
\hline \multirow{2}{*}{$\begin{array}{l}\text { Planning Areas and } \\
\text { Administrative Regions }\end{array}$} & \multirow[t]{2}{*}{ Population * } & \multicolumn{2}{|c|}{2012} & \multicolumn{2}{|c|}{2011} & \multicolumn{2}{|c|}{2010} & \multicolumn{2}{|c|}{2009} & \multicolumn{2}{|c|}{2008} & \multicolumn{2}{|c|}{2007} \\
\hline & & HA & Lep & HA & Lep & HA & Lep & HA & Lep & HA & Lep & HA & Lep \\
\hline Total & $6,320,446$ & 330 & 51 & 366 & 59 & 267 & 68 & 208 & 81 & 140 & 71 & 253 & 44 \\
\hline Planning Area 1 & 297,976 & 16 & 5 & 16 & 4 & 35 & 2 & 56 & 9 & 13 & 6 & 9 & 2 \\
\hline I. Portuária (Port) & 48,664 & 2 & 1 & 1 & 0 & 8 & 0 & 23 & 0 & 2 & 1 & 1 & 0 \\
\hline II. Centro (Downtown) & 41,142 & 1 & 0 & 0 & 0 & 0 & 0 & 4 & 1 & 0 & 0 & 1 & 0 \\
\hline III. Rio Comprido & 78,975 & 1 & 1 & 2 & 0 & 15 & 1 & 12 & 3 & 9 & 4 & 4 & 1 \\
\hline VII. São Cristóvão & 84,908 & 10 & 3 & 12 & 4 & 5 & 1 & 16 & 5 & 2 & 1 & 0 & 1 \\
\hline XXI. Paquetá & 3,361 & 0 & 0 & 0 & 0 & 0 & 0 & 1 & 0 & 0 & 0 & 0 & 0 \\
\hline XXIII. Santa Teresa & 40,926 & 2 & 0 & 1 & 0 & 7 & 0 & 0 & 0 & 0 & 0 & 3 & 0 \\
\hline Planning Area 2.1 & 638,050 & 10 & 1 & 16 & 1 & 6 & 2 & 5 & 3 & 25 & 1 & 9 & 1 \\
\hline IV. Botafogo & 239,729 & 5 & 0 & 7 & 0 & 0 & 1 & 1 & 1 & 1 & 0 & 5 & 0 \\
\hline V. Copacabana & 161,191 & 1 & 0 & 4 & 0 & 4 & 1 & 1 & 2 & 2 & 0 & 3 & 0 \\
\hline VI. Lagoa & 167,774 & 4 & 0 & 5 & 1 & 2 & 0 & 3 & 0 & 22 & 1 & 1 & 1 \\
\hline XXVII. Rocinha & 69,356 & 0 & 1 & 0 & 0 & 0 & 0 & 0 & 0 & 0 & 0 & 0 & 0 \\
\hline Planning Area 2.2 & 371,120 & 19 & 3 & 8 & 1 & 10 & 3 & 9 & 2 & 4 & 5 & 3 & 1 \\
\hline VIII. Tijuca & 181,810 & 2 & 1 & 8 & 0 & 8 & 1 & 9 & 1 & 2 & 1 & 1 & 0 \\
\hline IX. Vila Isabel & 189,310 & 17 & 2 & 0 & 1 & 2 & 2 & 0 & 1 & 2 & 4 & 2 & 1 \\
\hline Planning Area 3.1 & 886,551 & 108 & 8 & 88 & 8 & 77 & 15 & 51 & 19 & 37 & 13 & 29 & 7 \\
\hline X. Ramos & 153,177 & 42 & 1 & 35 & 2 & 11 & 4 & 14 & 6 & 6 & 4 & 1 & 1 \\
\hline XI. Penha & 321,887 & 52 & 3 & 24 & 3 & 15 & 8 & 8 & 7 & 2 & 6 & 3 & 5 \\
\hline XX. Ilha do Governador & 212,574 & 9 & 2 & 20 & 0 & 40 & 1 & 12 & 5 & 0 & 2 & 5 & 0 \\
\hline XXIX. Complexo do Alemão & 69,143 & 5 & 1 & 3 & 3 & 11 & 1 & 17 & 0 & 29 & 0 & 19 & 1 \\
\hline XXX. Maré & 129,770 & 0 & 1 & 6 & 0 & 0 & 1 & 0 & 1 & 0 & 1 & 1 & 0 \\
\hline Planning Area 3.2 & 569,970 & 44 & 4 & 74 & 6 & 37 & 9 & 15 & 9 & 9 & 6 & 23 & 9 \\
\hline XII. Inhaúma & 134,349 & 16 & 1 & 17 & 1 & 16 & 2 & 6 & 4 & 2 & 2 & 1 & 4 \\
\hline XIII. Méier & 397,782 & 20 & 3 & 57 & 4 & 21 & 5 & 9 & 5 & 7 & 3 & 22 & 4 \\
\hline XXVIII. Jacarezinho & 37,839 & 8 & 0 & 0 & 0 & 0 & 2 & 0 & 0 & 0 & 1 & 0 & 1 \\
\hline Planning Area 3.3 & 942,638 & 30 & 9 & 72 & 12 & 35 & 10 & 24 & 11 & 10 & 9 & 51 & 11 \\
\hline XIV. Irajá & 202,952 & 6 & 3 & 10 & 1 & 4 & 0 & 6 & 0 & 2 & 0 & 2 & 2 \\
\hline XV. Madureira & 372,555 & 15 & 5 & 30 & 5 & 12 & 7 & 7 & 9 & 2 & 4 & 18 & 6 \\
\hline XXII. Anchieta & 158,318 & 1 & 1 & 13 & 2 & 9 & 1 & 5 & 1 & 4 & 3 & 16 & 1 \\
\hline XXV. Pavuna & 208,813 & 8 & 0 & 19 & 4 & 10 & 2 & 6 & 1 & 2 & 2 & 15 & 2 \\
\hline Planning Area 4 & 909,368 & 34 & 6 & 38 & 13 & 23 & 13 & 23 & 10 & 14 & 8 & 23 & 5 \\
\hline XVI. Jacarepaguá & 572,030 & 26 & 3 & 32 & 9 & 14 & 7 & 19 & 6 & 10 & 7 & 20 & 2 \\
\hline XXXIV. Cidade de Deus & 36,515 & 4 & 2 & 1 & 1 & 1 & 2 & 1 & 3 & 1 & 1 & 1 & 3 \\
\hline XXIV. Barra da Tijuca & 300,823 & 4 & 1 & 5 & 3 & 8 & 4 & 3 & 1 & 3 & 0 & 2 & 0 \\
\hline Planning Area 5.1 & 671,041 & 4 & 3 & 5 & 2 & 8 & 1 & 7 & 3 & 8 & 4 & 6 & 2 \\
\hline XXXIII. Realengo & 243,006 & 2 & 2 & 1 & 2 & 2 & 0 & 5 & 1 & 2 & 1 & 3 & 1 \\
\hline XVII. Bangu & 428,035 & 2 & 1 & 4 & 0 & 6 & 1 & 2 & 2 & 6 & 3 & 3 & 1 \\
\hline Planning Area 5.2 & 665,198 & 48 & 10 & 40 & 9 & 26 & 10 & 12 & 12 & 16 & 18 & 83 & 5 \\
\hline XVIII. Campo Grande & 542,084 & 27 & 8 & 12 & 6 & 5 & 6 & 5 & 8 & 7 & 13 & 23 & 3 \\
\hline XXVI. Guaratiba & 123,114 & 21 & 2 & 28 & 3 & 21 & 4 & 7 & 4 & 9 & 5 & 60 & 2 \\
\hline Planning Area 5.3 & 368,534 & 8 & 1 & 5 & 1 & 1 & 2 & 0 & 0 & 1 & 1 & 10 & 1 \\
\hline XIX. Santa Cruz & 368,534 & 8 & 1 & 5 & 1 & 1 & 2 & 0 & 0 & 1 & 1 & 10 & 1 \\
\hline
\end{tabular}

* Population Census 201013.

$\mathrm{HA}=$ hepatitis $\mathrm{A}$; Lep = leptospirosis. 


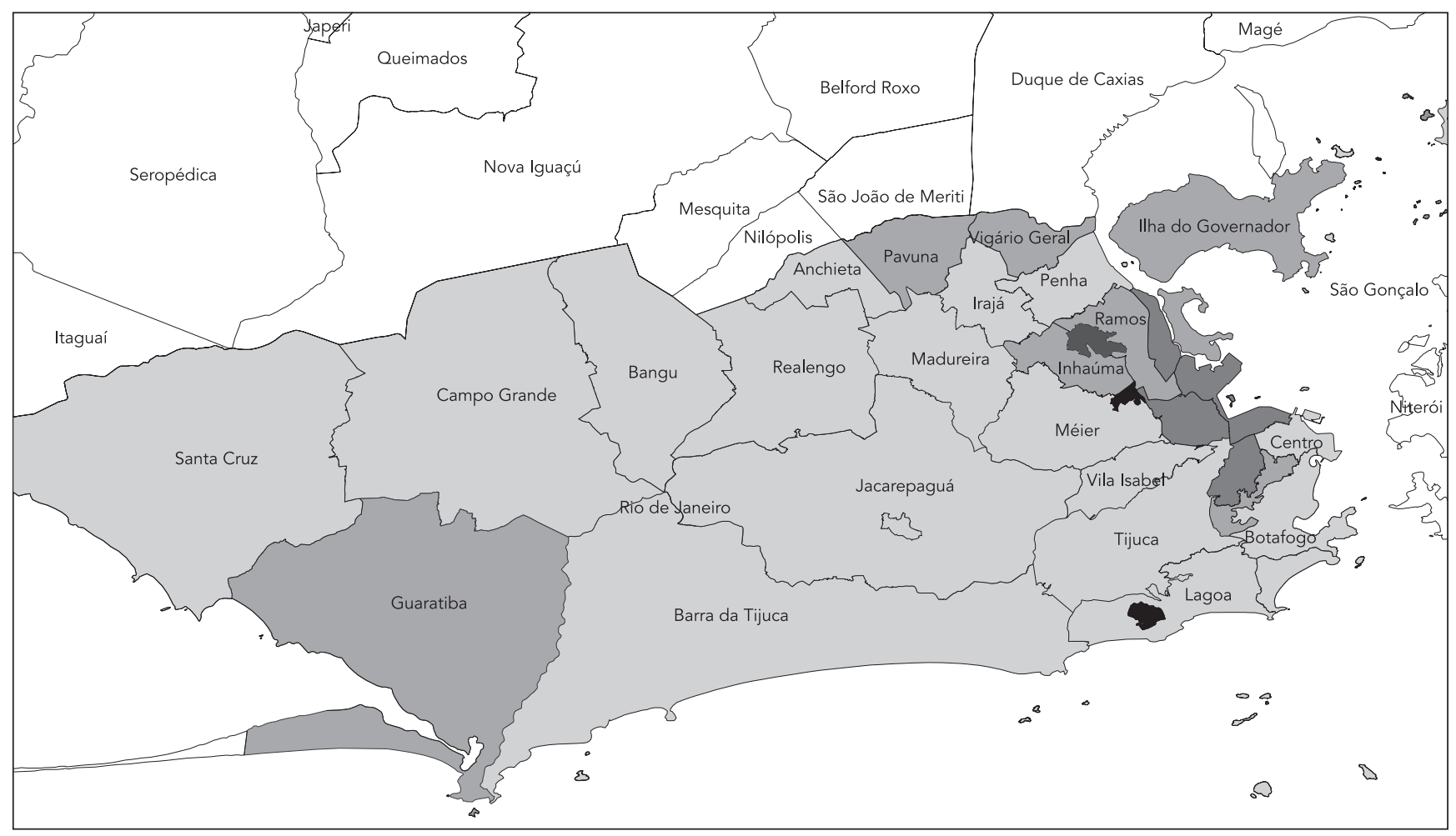

Households without accumulated garbage (\%)

$0.0-20.0$

$20.1-40.0$

$40.1-60.0$

$60.1-80.0$

$80.1-100.0$
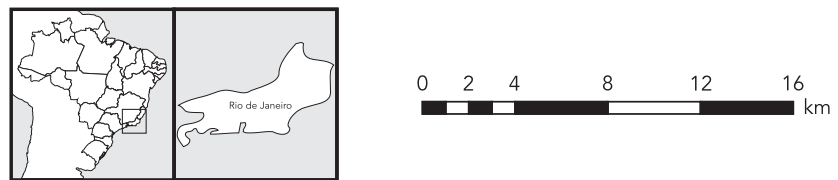

culty in projecting or even measuring the impacts from mega-events. Therefore, more in-depth discussions and analyses gain relevance in the Brazilian technical and scientific debate on this wide range of knowledge.

Thus the proposal for a multidisciplinary approach to the impacts of mega-events, although specifically dealing with the public health issue, leaving no doubt as to the cross-cutting and multi-sector approach of such a proposal.

The market model applied to urban planning and management in the city of Rio de Janeiro has thus produced the shortcomings that appeared in the 2007 Pan American Games. Public investments have benefited a "limited number of private companies" in flagrant misstep with "serving the basic needs of the population as a whole" 16 (p. 117).

The study identified persistent problems with health and access to urban services in areas excluded from the current Olympic planning, and historically excluded from government action in Rio de Janeiro. 
Figure 3

Proportion of households without open-air sewage in the vicinity. Rio de Janeiro, Brazil, 2010.

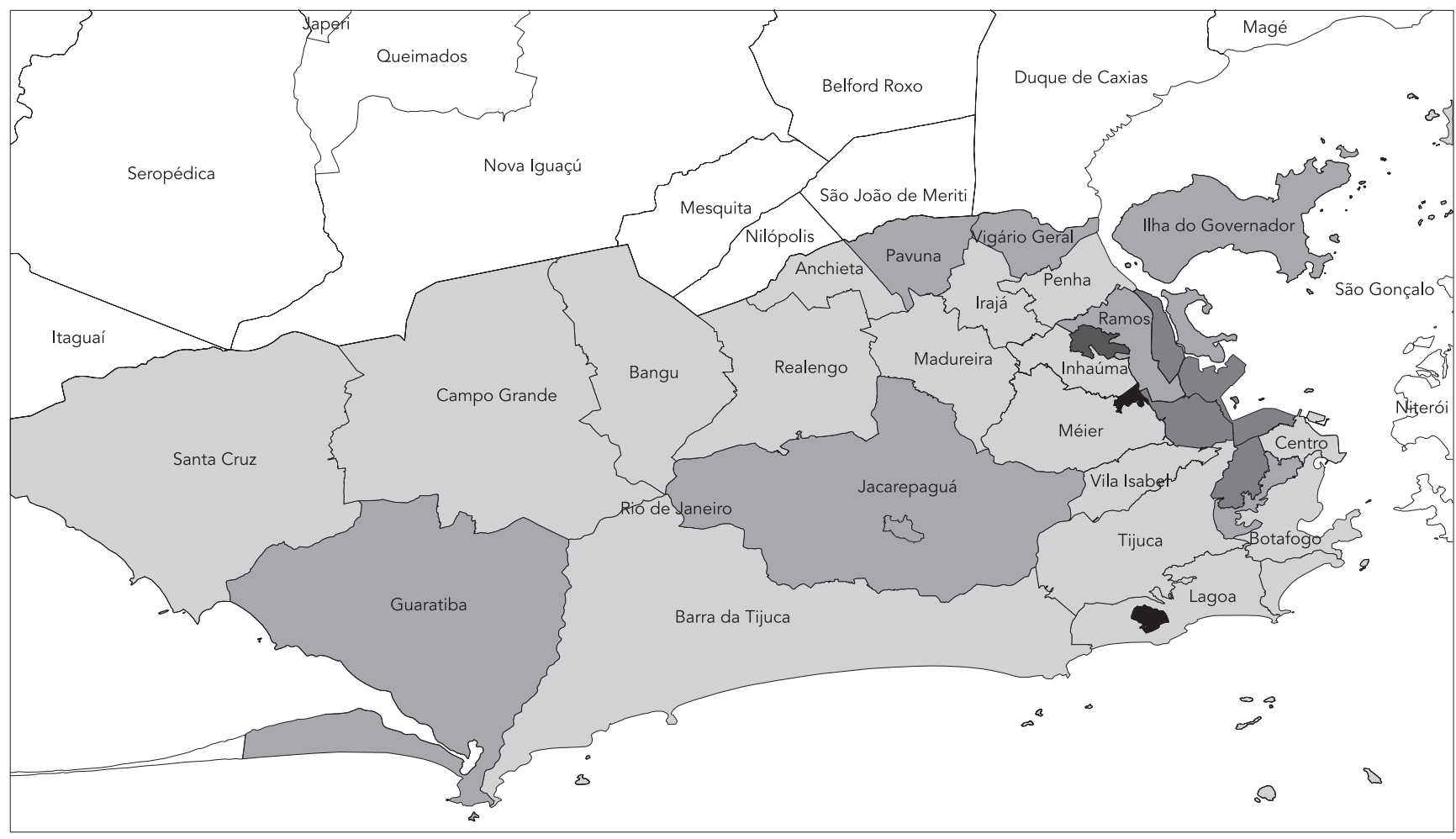

Households without open-air sewage (\%)

$0.0-20.0$

$20.1-40.0$

$40.1-60.0$

$60.1-80.0$

$80.1-100.0$
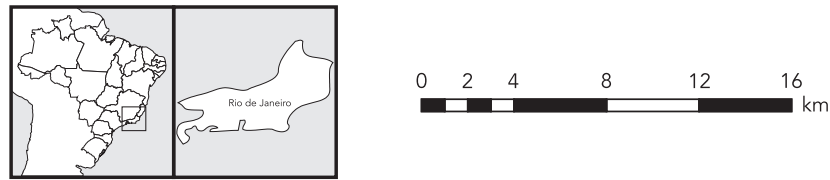

In conclusion, urban conditions and the market orientation of Olympic urban planning reveal a range of challenges for public health actions, seeking to combat the inequalities generated in this exclusionary planning which reshapes and appropriates Rio de Janeiro's urban space at the beginning of the new millennium. 


\section{Resumen}

El objetivo del presente trabajo es discutir las contradicciones del legado olímpico, en relación con la salud y el medio ambiente en la ciudad de Río de Janeiro, Brasil. Las políticas públicas, orientadas por los mega-eventos deportivos, son criticadas por contribuir y profundizar las históricas desigualdades socio-espaciales del municipio. Este trabajo, basado en una investigación documental y de análisis de datos, adoptó un enfoque dirigido a la construcción de una propuesta de ciudad sostenible, de acuerdo a lo establecido en la Ley 10.257/2001 del Estatuto de la ciudad. El trabajo concluye realizando consideraciones generales y específicas sobre el urbanismo olímpico, su orientación según la lógica del mercado y los errores en la superación de problemas de salud pública y saneamiento ambiental que permanecerán como herencia tras el 2016.

Planificación de Ciudades; Saneamiento; Salud Urbana

\section{Contributors}

R. M. Vilani and C. J. S. Machado provided the conceptualization, study structure, and writing of the article.

\section{Acknowledgments}

The authors wish to thank the Graduate Studies Program in Biodiversity and Health of the Oswaldo Cruz Institute, Oswaldo Cruz Foundation, for the post-doctoral funding, the results of which led to the reflections presented above.

\section{References}

1. Cardoso BV. Megaeventos esportivos e modernização tecnológica: planos e discursos sobre o legado em segurança pública. Horizontes Antropológicos 2013; 19:119-48.

2. Curi M. A disputa pelo legado em megaeventos esportivos no Brasil. Horizontes Antropológicos 2013; 19:65-88.

3. Dominguez Vila T, Darcy S, Alen E. Juegos olímpicos y paralímpicos en Brasil: aprendiendo de Barcelona y Sidney. Revista de Administração de Empresas 2014; 54:222-30.

4. Demarzo MMP, Mahtani KR, Slight SP, Barton C, Blakeman T, Protheroe J. The Olympic legacy for Brazil: is it a public health issue? Cad Saúde Pública 2014; 30:8-10.

5. Magalhães A. O "legado" dos megaeventos esportivos: a reatualização da remoção de favelas no Rio de Janeiro. Horizontes Antropológicos 2013; 19:89-118.

6. Paiva LR, Medeiros MGP, Álvares LMP. O paradigma neoliberal e os megaeventos: como a copa e as olimpíadas servem à produção de cidades mais excludentes no Brasil. In: Encontro da Associação Nacional de Pós-Graduação e Pesquisa em Planejamento Urbano e Regional. http://www. xvenanpur.com.br/anais.php (accessed on 03/ Apr/2014).
7. Mascarenhas G. O ideário urbanístico em torno do olimpismo: Barcelona (1992) e Rio de Janeiro (2007). In: Mascarenhas G, Bienenstein G, Sánchez F, editors. O jogo continua: megaeventos esportivos e cidades. Rio de Janeiro: EdUERJ; 2011. p. 41-56.

8. Bobbio N. A era dos direitos. Rio de Janeiro: Elsevier; 2004

9. Brauner MCC, Zaro L. Saúde e meio ambiente: fatores condicionantes para a concretização do direito à saúde. Juris 2012; 17: 53-74.

10. Maricato E. Brasil, cidades: alternativas para a crise urbana. Petrópolis: Editora Vozes; 2001.

11. Coordenação de Aperfeiçoamento de Pessoal de Nível Superior. Contribuição da pós-graduação brasileira para o desenvolvimento sustentável: Capes na Rio+20. Brasília: Coordenação de Aperfeiçoamento de Pessoal de Nível Superior; 2012.

12. Instituto Trata Brasil. Instituto Trata Brasil divulga ranking do saneamento com avaliação dos serviços nas 81 maiores cidades do País. http://www. tratabrasil.org.br (accessed on 06/Nov/2012).

13. Instituto Brasileiro de Geografia e Estatística. Censo demográfico 2010: características urbanísticas do entorno dos domicílios. Rio de Janeiro: Instituto Brasileiro de Geografia e Estatística; 2010. 
14. Saule Júnior N. Estatuto da Cidade e Plano Diretor: possibilidade de uma nova ordem legal urbana justa e democrática. In: Osório LM, editor. Estatuto da Cidade: novas perspectivas para as cidades brasileiras. Porto Alegre: Sergio Antonio Fabris; 2002. p. 77-119.

15. Mascarenhas G. Desenvolvimento urbano e grandes eventos esportivos: o legado olímpico dos jogos. In: Mascarenhas G, Bienenstein G, Sánchez F editors. O jogo continua: megaeventos esportivos e cidades. Rio de Janeiro: EdUERJ; 2011. p. 27-39.

16. Sánchez F, Bienenstein G, Oliveira A, Novais P, Oliveira FL, Cruz MCM, et al. Jogos Pan-Americanos Rio 2007: um balanço multidimensional. In: Mascarenhas G, Bienenstein G, Sánchez F, editors. O jogo continua: megaeventos esportivos e cidades. Rio de Janeiro: EdUERJ; 2011. p. 99-122.

17. Souza C. Política pública: uma revisão de literatura. Sociologias 2006; 16:20-45.

18. Saiani CSS, Toneto Junior R, Dourado JA. Déficit de acesso a serviços de saneamento ambiental: evidências de uma Curva Ambiental de Kuznets para o caso dos municípios brasileiros? Economia e Sociedade 2013; 22:791-824.

19. Heller L. Relação entre saúde e saneamento na perspectiva do desenvolvimento. Ciênc Saúde Coletiva 1998; 3:73-84.

20. Giovanella L, organizador. Políticas e sistema de saúde no Brasil. Rio de Janeiro: Editora Fiocruz; 2008.

21. The Lancet. Saúde no Brasil. http://bit.ly/lgQrDko (accessed on 10/May/2012).

22. Lustig RH, Schmidt LA, Brindis CD. The toxic truth about sugar. Nature 2012; 482:27-9.

23. Fundo de População das Nações Unidas. Relatório sobre a situação da população mundial 2011. New York: Fundo de População das Nações Unidas; 2011.

24. United Nations. The future we want. Rio de Janeiro: United Nations Conference on Sustainable Development; 2012.

25. Domingues EP, Betarelli Junior AA, Magalhães AS. Quanto vale o show?: Impactos econômicos dos investimentos da Copa do Mundo 2014 no Brasil. Estudos Econômicos 2011; 41:409-39.
26. Romanchuk E. Long-term effects estimation of mega-sport events on hosting countries with transition economies. In: 7th Silk Road International Conference "Challenges and Opportunities of Sustainable Economic Development in Eurasian Countries". http://bit.ly/1tLyHKs (accessed on 10/ Sep/2014).

27. Instituto Trata Brasil. Ranking do saneamento. http://www.tratabrasil.org.br (accessed on 20/ Mar/2014).

28. Departamento de Vigilância Epidemiológica, Secretaria de Vigilância em Saúde, Ministério da Saúde. Doenças infecciosas e parasitárias: guia de bolso. Brasília: Ministério da Saúde; 2010.

29. Soares SRA, Bernardes RS, Cordeiro Netto OM. Relações entre saneamento, saúde pública e meio ambiente: elementos para formulação de um modelo de planejamento em saneamento. Cad Saúde Pública 2002; 18:1713-24.

30. Vianna MSR. A transmissão da leptospirose em áreas urbanas. Boletim de Divulgação Técnica e Científica 2001; 10:6-8.

31. Machado CJS, Filipecki ATP. A paisagem do trabalho científico e o uso de animais em pesquisas domésticas. In: Machado CJS, editor. Ciências, políticas públicas e sociedade sustentável. Rio de Janeiro: E-papers; 2012. p. 43-101.

32. Machado CJS, Vilani RM, Godinho RS. Royalties do petróleo e política de preservação da biodiversidade. In: Machado CJS, editor. Ciências, políticas públicas e sociedade sustentável. Rio de Janeiro: E-papers; 2012. p. 149-89.

33. Ribeiro RJC. Projeto Metropolização e Megaeventos: os impactos da Copa do Mundo 2014 e das Olimpíadas 2016. http://bit.ly/WWqKUF (accessed on 10/Sep/2014).

34. Damo AS, Oliven RG. O Brasil no horizonte dos megaeventos esportivos de 2014 e 2016. Horizontes Antropológicos 2013; 19:19-63.

Submitted on 02/Apr/2014

Final version resubmitted on 19/Sep/2014

Approved on 15/Oct/2014 